\title{
水酸化アルミニウムのメカニカル活性化による水和活性 微粒子材料の調製とセメント速硬化機能
}

\author{
Preparation of Active Hydrated Alumina by Mechanical \\ Activation and its Application to Rapid Cement Hardener
}

\author{
北村 真 ${ }^{\mathrm{a}}$, 佐原 敬 ${ }^{\mathrm{a}}$, 宮崎 幸 ${ }^{\mathrm{a}}$, 神谷 昌岳 ${ }^{\mathrm{a}}$, 仙名 保 ${ }^{\mathrm{b}}$ \\ Makoto Kitamura, Takashi Sahara, Miyuki Miyazaki, Masataka Kamitani, Mamoru Senna
}

Received 29 May 2001; Accepted 6 August 2001

Milling of gibbsite by an agitation ball mill brought about mechanochemical dehydration and amorphization. A remarkable increase in hydration reactivity with $\mathrm{Ca}(\mathrm{OH})_{2}$ is demonstrated by using a conduction calorimeter. An integral heat of hydration from mechanically activated gibbsite is about 300 times larger than that from the intact gibbsite. We found high correlation between the integral heat of hydration and the $3 \mathrm{~h}$ compressive strength of conventional Portland cement paste containing milled gibbsite with or without $\mathrm{Ca}(\mathrm{OH})_{2}$. Acquired high activity of milled gibbsite was sustained for at least 2 months under $50 \% \mathrm{RH}$. These properties warrant applicability of mechanically activated gibbsite to rapid hardening agents for Portland cement.

Key Words : Gibbsite, Mechanical activation, Hydration reactivity, Rapid hardening

\section{1. 緒 言}

物質に機械的エネルギーを作用させると，微粒子化 が生じ比表面積が増加するのみならず格子不整・欠陥 の導入による非晶質化 ${ }^{1)}$ や相転移 ${ }^{2}$ などの物理化学的 な変化を引き起こすことが多くの物質で報告されてい る。建築材料分野においても，セメントクリンカーの 機械的活性化により早期に高い強度が発現するコンク リートの調製が可能であることが報告されている3 ${ }^{3)}$ か, カオリナイトの摩砕処理により水ガラスとの重縮 合反応が促進され高強度な硬化体を作製できることも 報告されている ${ }^{4)}$ 。また，二種類の異なる酸化物およ び水酸化物を出発物質とした混合摩砕により複合酸化 物が得られることを利用してカルシウムシリケート前

\footnotetext{
a 積水化学工業 (株) 京都研究所無機材グループ

（テ601-8105 京都市南区上鳥羽上調子町 2-2）TEL 075-662-8529 Sekisui Chemical Co. Ltd. Inorganic Technology Group Kyoto Research Lab.

(2-2, Kamichoshi-cho, Kamitoba, Minami-ku, Kyoto, 601-8105)

$\mathrm{b}$ 慶応義塾大学理工学部応用化学科

（テ223-8522 横浜市港北区日吉 3-14- 1) TEL 045-564-0950 Keio University, Faculty of Seience and Technology, Department of Applied Chemistry

(3-14-1, Hiyoshi, Kohoku-ku, Yokohama, 223-8522)
}

駆体 ${ }^{5)}$, カルシウムシリケート水和物 ${ }^{6)}$ およびカルシ ウムアルミネート水和物 ${ }^{7)}$ などが得られることが報告 されている。

著者らは, メカニカル活性化処理した $\mathrm{Al}(\mathrm{OH})_{3}$ と $\mathrm{Ca}(\mathrm{OH})_{2}$ からなる混合物がセメント速硬化剂として 優れた特性を有し，室温で水和活性粉体を作製できる ことを示した ${ }^{8)}$ 。これは, $\mathrm{Al}(\mathrm{OH})_{3}$ の摩砕に伴って $\mathrm{Ca}(\mathrm{OH})_{2}$ との水和反応性が高まり, セメントペース ト中でカルシウムアルミネート水和物が速やかに生成 することによる ${ }^{9)}$ 。 $\mathrm{Al}(\mathrm{OH})_{3}$ の摩砕によるメ力ノケ ミカル変化については, 熱的相転移への影響に関して 報告されているものの ${ }^{10)}$ ，水和活性に関する報告例は ない。摩砕に伴う $\mathrm{Al}(\mathrm{OH})_{3}$ の水和活性化は比表面積 の増加によるものだけでなく，むしろ非晶質化に伴う 構造変化によってもたらされるものと考えられる。著 者らは既に, 摩砕した $\mathrm{Al}(\mathrm{OH})_{3}$ を絶縁溶媒中に分散 させたサスペンジョンにおいて，電場印加によりレオ ロジー特性が大きく変化するエレクトロレオロジ一特 性を報告しており ${ }^{11)}$ ，摩砕に伴ってメカノケミカル脱 水し再度吸着した水分子の分極に関する知見を有して いる。

本研究の目的は, カロリーメトリーによって摩砕に 伴う $\mathrm{Al}(\mathrm{OH})_{3}$ の水和反応に対する活性の度合を定量 
的に記述するとともに, 水和活性の度合と, より実用 的なセメントペーストの速硬化性能との相関性を検討 することにある。得られる結果は硬化速度を予測する 手法として有用である。さらに, 速硬化剂としての水 和活性 $\mathrm{Al}(\mathrm{OH})_{3}$ 微粒子の実用化に不可欠な水和活性 度の保存安定性について検討する。 $\mathrm{Al}(\mathrm{OH})_{3}$ の水和 活性度は, 水和熱のカロリーメトリーにより定量でき る。また, セメント速硬化性能については凝結速度, 圧縮強度の発現性により定量化し，この相関について 議論する。水和活性度の保存安定性は摩砕直後からの $\mathrm{Al}(\mathrm{OH})_{3}$ の水和活性の経時変化に基づいて検討する。

\section{2. 実験方法}

\section{1 試料調製}

試料には工業用水酸化アルミニウム（ギブサイト， 純度 $99.8 \%$, 比表面積 $0.21 \mathrm{~m}^{2} / \mathrm{g}$, 住友化学 (株), C-31), 工業用水酸化カルシウム（純度 $99.7 \%$, 比 表面積 $13.8 \mathrm{~m}^{2} / \mathrm{g}$, 河合石灰工業（株））を用いた。水 酸化アルミニウムの摩砕には内外筒相互回転型の媒体 擋找型ミル (UF ミル, AT-25, 三菱重工 (株)) を用 $\left(^{12)}\right.$, 内筒と外筒間の空間 $(15 l)$ に粉砕媒体 $45 \mathrm{~kg}$, 試料 $1.5 \mathrm{~kg}$ を投入し, 内筒, 外筒相互に $105 \mathrm{rpm}$ で 逆方向に回転させ, 常代密閉容器中で乾式粉砕を行っ た。粉砕媒体には直径 $10 \mathrm{~mm}$ のジルコニアボール (YTZ, ニッカトー) を用いた。

\section{2 摩砕試料の特性}

粒度分布はレーザー回折型粒度分布測定装置（SK Laser Micron Sizer, セイシン企業) により測定し た。非晶質化度はX線回折装置（RINT-1100, 理学 (株)）により CuK $\boldsymbol{\alpha}$ 線を用いて測定した。内部標準物 質として $\mathrm{MgO}$ を $10 \mathrm{wt} \%$ 添加し， MgO (200) 面の ピークに対するギブサイト（002）面のピーク強度を 求めた。非晶質化度は， $\left(1-\mathrm{I}^{*} / \mathrm{I}_{0}\right) \times 100(\%)$ によ って定義した。ここで I* は摩砕した試料のピーク強 度, $\mathrm{I}_{0}$ は未処理試料のピーク強度である。 $\mathrm{OH}$ 基の脱 水挙動は熱重量/示差熱分析装置 (TG/DTA320, 七 イコー電子工業 (株))により, 大気中でミルより取り 出した摩砕直後の試料について前処理を行わずに昇温 速度 $10^{\circ} \mathrm{C} /$ 分, 大気中で測定した。得られた $\mathrm{TG}$ 曲線 より, $200^{\circ} \mathrm{C}$ までの重量変化 $\left(\mathrm{A}_{2000^{\circ} \mathrm{C}}\right)$ と $1300^{\circ} \mathrm{C}$ まで の重量変化 $\left(\mathrm{A}_{1300^{\circ} \mathrm{C}}\right)$ を読み取った。また, 摩砕試料 の経時変化は $\mathrm{KBr}$ 法を用いた IR スペクトル (FT-IR 1640 型, パーキンエルマ(株))により評価した。

\section{3 水和活性度とセメント速硬化性}

コンダクションカロリーメーター（MMC5111，東
京理工 (株)）を用いて, 水酸化アルミニウム $1 \mathrm{~g}$ 当た りの注水後 1 時間後および 3 時間後までの積分発熱量 を求め, 水酸化アルミニウムの水和活性度の尺度とし た。水酸化アルミニウムのみの水和活性度は, 水酸化 アルミニウム $2 \mathrm{~g}$, 水 $6 \mathrm{~g}$ の比率で測定した。また, 水酸化アルミニウムと水酸化カルシウムとの水和活性 度は, 水酸化アルミニウム $1 \mathrm{~g}$, 水酸化カルシウム $1 \mathrm{~g}$, 水 $6 \mathrm{~g}$ の比率で, $25^{\circ} \mathrm{C}$ の一定温度下で測定を行 った。

セメント速硬化性については, 摩砕した水酸化アル ミニウムを添加したセメントペーストについて JIS R 5201 の凝結試験機のビガー針を用いた始発, 終結時 間と注水 3 時間後の圧縮強度 (JIS R 5201) により測 定した。すなわち, 始発時間はビガー針がセメント ペーストの最底部より $1 \mathrm{~mm}$ 上昇した時点から, 終結 時間はセメントペーストの最上面よりビガー針が侵入 しなくなった時点からそれぞれ判定した。セメント ペーストは, 普通ポルトランドセメント（太平洋セメ ント), 摩砕した水酸化アルミニウム, 水酸化カルシ ウムを重量比で $87: 6.5: 6.5$ の割合で混合後, 水を 30 部添加し混練することで調製した。このようなペース トの調製条件は, 水酸化アルミニウムと水酸化カルシ ウムの比率が速硬化性に与える影響など，以前に著者 らが報告した, 優れた速硬化性を得るために最適な配 合条件に基づいている ${ }^{8)}$ 。また，比較のため水酸化ア ルミニウムのみを添加した系では, セメント, 水酸化 アルミニウムを $87: 13$ の割合で同样の水比で混練し た。压縮強度測定には直径 $50 \mathrm{~mm}$, 長さ $100 \mathrm{~mm}$ の 円筒状に注型したサンプルを用いた。

\section{3. 結果と考察}

\section{1 摩砕に伴う構造変化}

Fig. 1 に示すように, 摩砕によりギブサイトの微細 化と共に顕著な非晶質化が同時に確認され, 幾何学的 な変化のみならず結晶学的な構造変化も生じている。 ただし，微細化は 0.5 時間でほぼ終了するのに対し， 非晶質化は摩砕時間と共に漸增し， 5 時間では $90 \%$ 以上に達した。

Fig. 2 a), b) に, 摩砕直後のギブサイトの DTA， TG曲線をそれぞれ示す。DTA曲線において，未処 理のギブサイトでは $250{ }^{\circ} \mathrm{C}$ おび $300^{\circ} \mathrm{C}$ 付近に $\mathrm{OH}$ 基の脱水に起因する吸熱ピーク ${ }^{10)}$ が観察されるが, 摩砕に伴いこれらのピーク強度は減少し低温側にシフ トする。 5 時間摩砕試料では $100{ }^{\circ} \mathrm{C}$ 付近に新たな吸 熱ピークが形成される。一方, 対応する TG 曲線で 


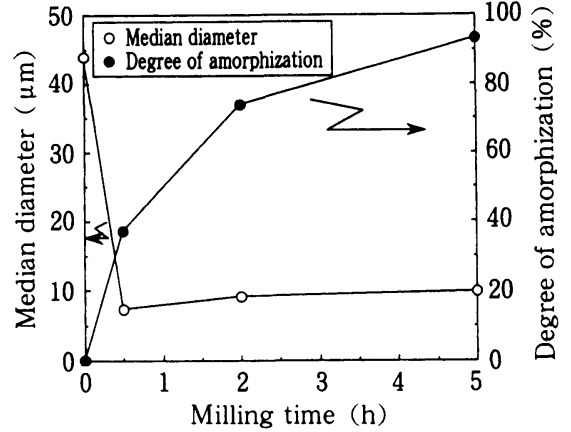

Fig. 1 Change in median diameter and degree of amorphization for gibbsite with milling time

A) DTA curves

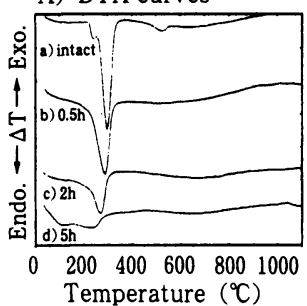

Fig. 2 (A) DTA and (B) TG curves of milled gibbsite for various milling time

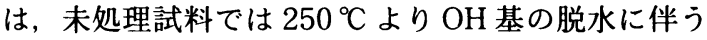
重量减少が開始するが, 摩砕試料では $200{ }^{\circ} \mathrm{C}$ 以下の 低温側から重量減少が開始している。この様な 200 ${ }^{\circ} \mathrm{C}$ 以下での重量减少は, 密閉容器中での摩砕によ り,メカノケミカル脱水した水が, 摩砕粒子表面に再 吸着した物理吸着水であると考えられる。従って， $200{ }^{\circ} \mathrm{C}$ を境に物理吸着水と構造水とに区別を行った。 この様なメカノケミカル脱水は, 結晶構造に由来する 空孔子点を有するギブサイトでは他の水酸化物に比べ て生じやすいことが Liaoらによって報告されてい $3^{13)}$ 。

Fig. 3 に, $200{ }^{\circ} \mathrm{C}, 1300^{\circ} \mathrm{C}$ における重量減少と摩砕 時間との関係を示す。 $1300{ }^{\circ} \mathrm{C}$ における脱水量は摩砕 により大きな変化は認められないが, $200{ }^{\circ} \mathrm{C}$ におけ る脱水量は，摩砕 5 時間まで単調に増加している。右 縦軸には $1300^{\circ} \mathrm{C}$ までの脱水量に占める $200^{\circ} \mathrm{C}$ での脱 水量の割合を示す。摩砕 5 時間ではメカノケミカル脱 水により約 $50 \%$ もの物理吸着水が存在している。著 者らは, ギブサイトの摩砕における前加熱の影響の検 討において，加熱による $50 \%$ もの脱水はベーマイト の生成を伴うが, 摩砕処理のみによるメカノケミカル 脱水においてはベーマイトやアルミナなどの結晶相は

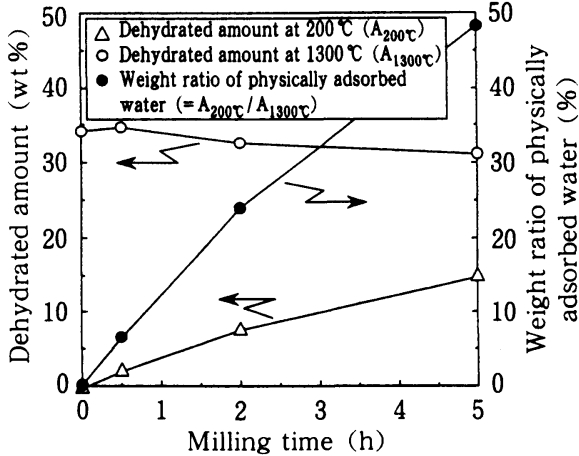

Fig. 3 Change in dehydrated amount from milled gibbsite at various temperatures with milling time

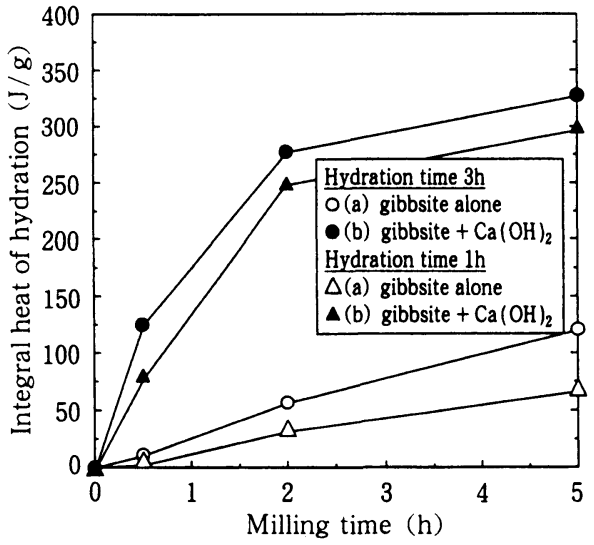

Fig. 4 Change in integral heat of hydration per unit weight of gibbsite for (a) gibbsite alone and (b) gibbsite with $\mathrm{Ca}(\mathrm{OH})_{2}$ at various hydration time with milling time

X線回折によって観察されなかった ${ }^{9)}$ 。

\section{2 水和活性とセメント速硬化性}

Fig. 4 に，摩砕時間と注水 1 時間， 3 時間後のギブ サイトの水和による積分発熱量を示す。同じ摩砕時間 のギブサイトを用いた場合でも， $\mathrm{Ca}(\mathrm{OH})_{2}$ 共存下て はギブサイト単独の場合より発熱量が約 3 倍以上大き い。 $\mathrm{Ca}(\mathrm{OH})_{2}$ 自体の水和熱は, $8.5 \mathrm{~J} / \mathrm{g}$ とわずかであ ることから, $\mathrm{Ca}(\mathrm{OH})_{2}$ 共存下ではギブサイトの水和 反応が促進されていると考えられる。著者らは，摩 砕ギブサイトを絶縁溶媒中に分散したサスペンジョ ンのエレクトロレオロジーの測定により，摩砕した ギブサイトの表面吸着水の分極を報告している ${ }^{11}$ 。こ の様な分極サイトが固体酸点となり，アルカリ溶液て ある $\mathrm{Ca}(\mathrm{OH})_{2}$ 水溶液中で溶解反応が促進され, 対イ オンである Ca イオンとの溶解再析出反応によりカル 


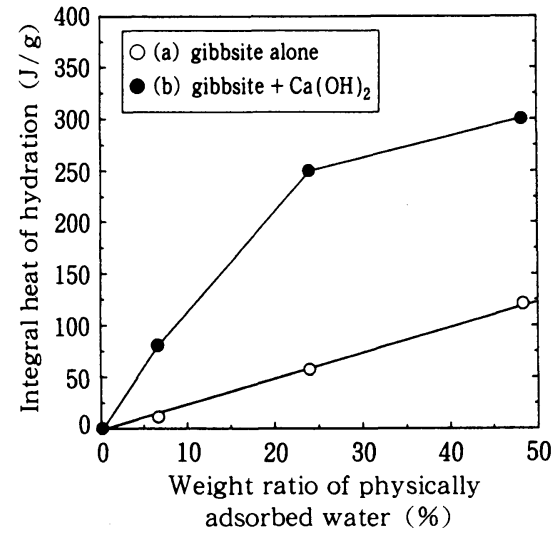

Fig. 5 Relation between the weight ratio of physically adsorbed water and the integral heat of hydration for (a) gibbsite alone and (b) gibbsite with $\mathrm{Ca}(\mathrm{OH})_{2} 3 \mathrm{~h}$ after casting

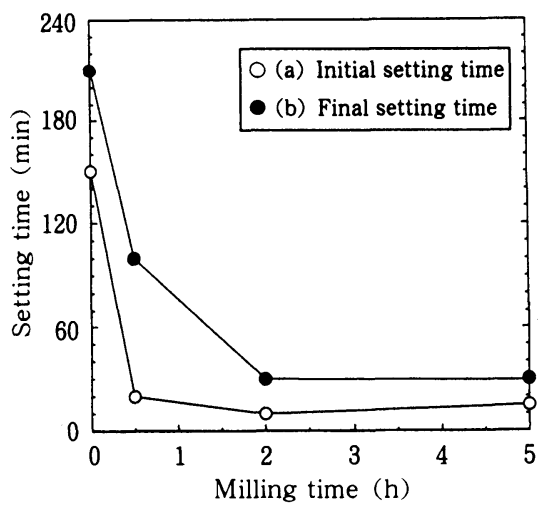

Fig. 6 Change in (a) initial and (b) final setting time of cement added gibbsite with $\mathrm{Ca}(\mathrm{OH})_{2}$ with milling time

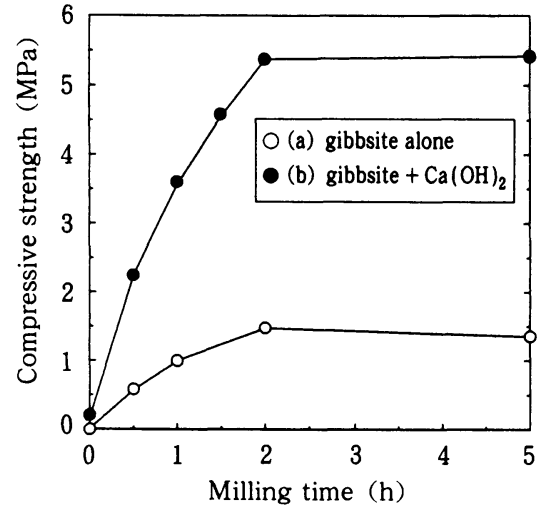

Fig. 7 Change in compressive strength of cement added (a) gibbsite alone and (b) gibbsite with $\mathrm{Ca}(\mathrm{OH})_{2} 3 \mathrm{~h}$ after casting with milling time

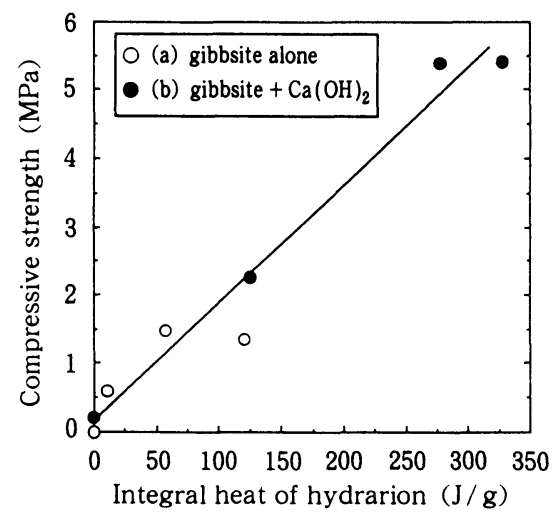

Fig. 8 Relation between the integral heat of hydration and the compressive strength of cement added

(a) gibbsite alone and (b) gibbsite with $\mathrm{Ca}(\mathrm{OH})_{2} 3 \mathrm{~h}$ after casting
シウムアルミネート水和物が生成することが, 水和反 応促進の主な機構と考えられる。摩砕ギブサイトの $\mathrm{Ca}(\mathrm{OH})_{2}$ との水和反応による生成物については, 水 和初期の 3 時間までに $3 \mathrm{CaO} \cdot \mathrm{Al}_{2} \mathrm{O}_{3} \cdot 6 \mathrm{H}_{2} \mathrm{O}$ を主成分 としたカルシウムアルミネート水和物として生成して いることをX線回折や SEM によるモルフォロジー観 察によって明らかにしている ${ }^{8)}$ 。一方，Fig. 5 に示す ように，ギブサイト単独での発熱量は，Fig. $3 て ゙$ 確認 された $200{ }^{\circ} \mathrm{C}$ 以下で脱水する物理吸着水量と良好な 比例関係にあり, メカノケミカルに脱水した表面サイ 卜に水分子が再吸着し水和反応を生じるため発熱する と考えられる。

Fig. 6 に，摩砕したギブサイトと $\mathrm{Ca}(\mathrm{OH})_{2}$ を添加
したセメントペーストの凝結時間を示す。ギブサイト の摩砕時間の増加により, 凝結の始発, 終結ともに短 縮され，摩砕 2 時間以降では大きな変化は見られず, 注水 30 分後では凝結が終結している。

Fig. 7 に, 同様のセメントペーストの注水 3 時間後 の压縮強度とギブサイトの摩砕時間との関係を示す。 摩砕により王縮強度は影著に増加するが, 摩砕 2 時間 以降は大きな変化が認められない。一方，比較のため に摩砕したギブサイトのみを添加したセメントペース 卜と比較すると約 3 倍以上の強度を示している。これ らの強度発現の挙動は, Fig. 4 の水和発熱量の関係と よく似ている。事実，Fig. 8 に示すように，3時間ま での積分発熱量と, 同じ材齢である 3 時間後の圧縮強 


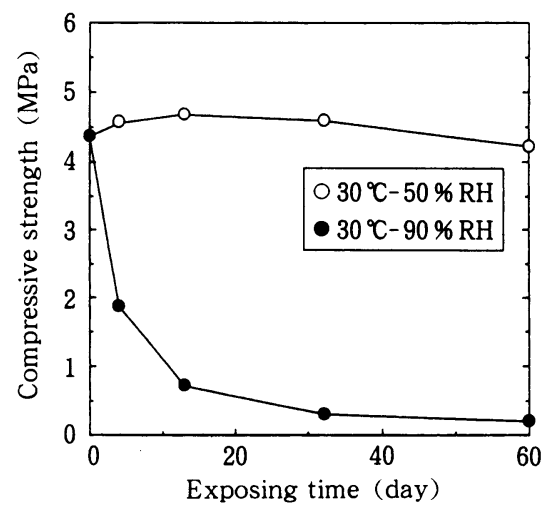

Fig. 9 Change in compressive strength of cement added gibbsite exposed at (a) $30{ }^{\circ} \mathrm{C}-50 \%$ $\mathrm{RH}$ and (b) $30{ }^{\circ} \mathrm{C}-90 \% \mathrm{RH}$ after milling for $1.5 \mathrm{~h}$ with $\mathrm{Ca}(\mathrm{OH})_{2}$

度との間には良好な比例関係がある。3時間までの積 分発熱量は，摩砕により活性化されたギブサイトと $\mathrm{Ca}(\mathrm{OH})_{2}$ との水和反応によるカルシウムアルミネー 卜水和物 $(\mathrm{CAH})$ の生成反応による水和発熱量を示し ているため, 水和 3 時間までの強度発現性, すなわち 速硬化性は $\mathrm{CAH}$ の生成によるものと示唆され, 従っ て, カロリーメーターによるギブサイトの水和発熱量 の測定により速硬化性が予測可能である。

\section{3 水和活性の経時変化}

Fig. 9 に, 摩砕試料を温度 $30{ }^{\circ} \mathrm{C}$, 相対湿度 $50 \%$, $90 \%$ の二つの湿度環境下で保持した時の, 保持時間 と 3 時間圧縮強度の関係を示す。相対湿度 $50 \%$ では 60 日後でも強度は摩砕直後とほとんど変化が認めら れない。これに対して, 相対湿度 $90 \%$ 保持では 3 時 間圧縮強度は 60 日間で約 $1 / 20$ に減少する。この様な 水和活性の失活は, 摩砕したギブサイト粒子表面が大 気中の水分子を吸着し局所的に水和反応が進行し, $\mathrm{Ca}(\mathrm{OH})_{2}$ と反応して $\mathrm{CAH}$ を生成する段階での活性 が損なわれたためと考えられる。Fig. 10 に摩砕直後 および 14 日保持後の試料の IR スペクトルを示す。摩 砕によりギブサイトの $\mathrm{OH}$ 基固有の $3500,1000,450$ $\mathrm{cm}^{-1}$ 付近のピークがブロード化する。一方，14日保 持後では相対湿度 $90 \%$ 保持では, 図中, 矢印で示す ようにピークが明確に分離できるようになり摩砕前 のギブサイトの状態へと緩和されている。このよう な反応は Fig. 11 に示す様に, 相対湿度 $90 \%$ 保持で は，ギブサイトの非晶質化度が 14 日後には $75 \%$ から $52 \%$ へと変化していることから再結晶化を伴うこと が確認された。高湿度下では物理吸着水が多層吸着し 自由水に近い状態で存在するため, 溶解再析出の溶媒

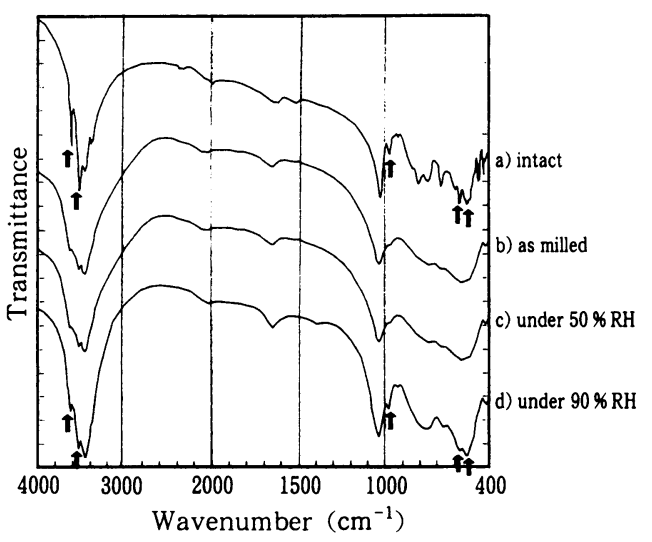

Fig. 10 IR spectra of gibbsite a) intact,

b) as milled for $2 \mathrm{~h}$,

c) soaked under $30{ }^{\circ} \mathrm{C}-50 \% \mathrm{RH}$ and

d) soaked under $30{ }^{\circ} \mathrm{C}-90 \% \mathrm{RH}$ for 14

days after milling for $2 \mathrm{~h}$

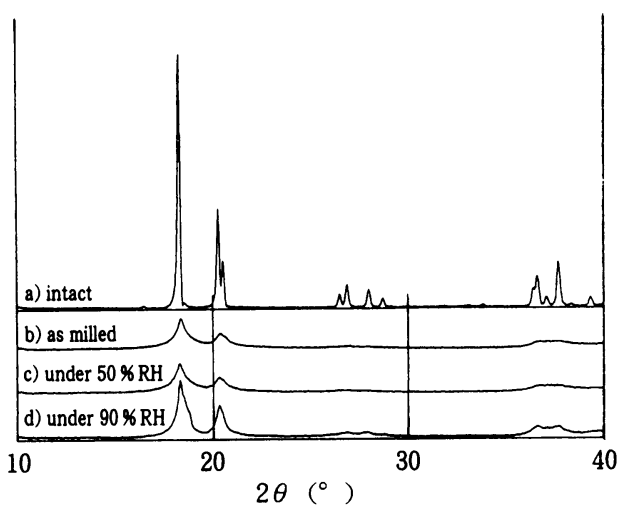

Fig. 11 XRD profiles of mechanically activated gibbsite a) intact, b) as milled,

c) soaked under $30^{\circ} \mathrm{C}-50 \% \mathrm{RH}$ and d) soaked under $30^{\circ} \mathrm{C}-90 \% \mathrm{RH}$ for 14 days after milling for $2 \mathrm{~h}$

として㗢いたいものと推測される。これに対して, $50 \% \mathrm{RH}$ 保持では, 高湿度下で認められる顕著な構 造変化が生じないことから, Fig. 2において確認され た摩砕時にメカニカル脱水し再吸着した水が物理吸着 水としてのみ存在し, 再結晶化などの摩砕前の状態へ の緩和反応は進行しなかったことを示している。

\section{4. まとめ}

工業的にスケールアップ可能な媒体擋拌型ミルによ り摩砕したギブサイトの構造変化, 水和活性度, 摩砕 ギブサイトを添加したセメントペーストの速硬化性能 を明らかにすると共に, 摩砕ギブサイトの活性度の保 
存性を検討するため，水和活性度の摩砕直後よりの経 時変化についても検討した結果, 次のことが明らかと なった。

1）摩砕に伴い微粒子化などの幾何学的な変化のみな らず，非晶質化やメカニカル脱水に伴う物理吸着水 量の増加などの影著な構造変化が生じる。

2 ) 摩砝によるギブサイトの水和活性度をカロリー メーターにより定量化でき, 摩砕時間の増加と共に ギブサイトの水和活性度が，特に $\mathrm{Ca}(\mathrm{OH})_{2}$ の共存 下で顕著（約 300 倍）に増大し，優れたセメント速
硬化性能を発現する。

3） 3 時間までの積分発熱量と 3 時間圧縮強度との間 に相関関係が得られ，摩砕ギブサイトと $\mathrm{Ca}(\mathrm{OH})_{2}$ との水和反応が速硬化性を支配している。

4 ）カロリーメーターによる水和発熱量の測定により 速硬化性が予測可能である。

5 ) 摩砕直後より発生する物理吸着水之の水和反応は X線回折や IR 測定によって認められず， 50 \% RH では少なくとも約 2 ケ月間活性を維持し工業的にも 十分に使用できる。

\section{References}

1) Sugiyama, K., J. M. Filio, F. Saito and Y. Waseda : "Structural change of kaolinite and phyrophyllite induced by dry grinding", Mineralogical Journal. 17, 28-41 (1994)

2) Iguchi, Y. and M. Senna : "Mechanochemical polymorphic transformation and its stationary state between aragonite and calcite", Powder Technology, 43, 155-162 (1985)

3) Opoczky, L. : "Fine Grinding and Agglomeration of Silicates”, Powder Technology, 17, 1-7 (1977)

4 ) Nakano, T., M. Kamitani and M. Senna : “A new inorganic bonding agent from mechanically activated kaolin", Material Science Forum, 225/227, 235 238 (1996)

5) Watanabe, T., T. Isobe and M. Senna : "Mechanisms of Incipient Chemical Reaction between $\mathrm{Ca}(\mathrm{OH})_{2}$ and $\mathrm{SiO}_{2}$ under Moderate Mechanical Stressing 1:A Solid State Acid-Base Reaction and Charge Transfer Due to Complex Formation", J. Solid. State. Chem., 122, 74-80 (1996)

6 ) Sasaki, K., T. Masuda, H. Ishida, T. Masuda and T. Mitsuda : "Synthesis of Calcium Silicate Hydrate with $\mathrm{Ca} / \mathrm{Si}=2$ by Mechanochemical Treatment", $J$. Am. Ceram. Soc., 80, 472-476 (1997)

7) Filio, J. M., R. V. Perucho, F. Saito, M. Hanada and Y. Ito: "Mechanosynthesis of Tricalcium Aluminum
Hydrate by Mixed Grinding", Mater. Sci. Forum, 225/ 227, 503-508 (1996)

8 ) Kitamura, M., M. Kamitani and M. Senna : “Rapid Hardening of Cement by the Addition of a Mechan ically Activated $\mathrm{Al}(\mathrm{OH})_{3}-\mathrm{Ca}(\mathrm{OH})_{2}$ Mixture", J. Am. Ceram. Soc., 83, 523-527 (2000)

9 ) Kitamura, M. and M. Senna : "Effects of preheating on mechanochemical amorphization and enhanced reactivity of aluminum hydroxide", Advanced Powder Technology, 12, No. 2, 215-226 (2001)

10) Tsuchida, T. and N. Ichikawa : “Mechanochemical phenomena of gibbsite, bayerite and boehmite by grinding", Reactivity of Solids, 7, 207-217 (1989)

11) Kitamura, M., M. Kamitani and M. Senna : "Electrorheological Properties of Mechanically Activated Gibbsite", $3^{\text {rd }}$ International Conference on Mechanochemistry and Mechanical Alloying, 18, September 2000 (Prague)

12) Miyazaki, M., M. Kamitani, T. Nagai, J. Kano and F. Saito: "Amorphization of kaolinite and media motion in grinding by a double rotating cylinders mill", Advanced Powder Technology, 11, 235-244 (2000)

13) Liao, J. and M. Senna : "Mechanochemical dehydration and amorphization of hydroxides of $\mathrm{Ca}, \mathrm{Mg}$ and $\mathrm{Al}$ on grinding with and without $\mathrm{SiO}_{2}{ }$, Solid State Ionics, 66, 313-319 (1993) 